\title{
Evaluation of physicochemical, nutritional, and organoleptic properties of nuggets based on moringa (Moringa oleifera) leaves and giant catfish (Arius thalassinus)
}

\author{
Enny SOLICHAH ${ }^{1+}$, Ade Chandara IWANSYAH ${ }^{2+*}$ (D), Devry PRAMESTI ${ }^{1+}$, Dewi DESNILASARI ${ }^{1}$ (D) , \\ Wawan AGUSTINA ${ }^{1}$, Woro SETIABOMA ${ }^{1}$, Ainia HERMINIATI ${ }^{1}$
}

\begin{abstract}
This study aimed to evaluate the physicochemical, nutritional, and organoleptic properties of nuggets based on Moringa oleifera leaves and Arius thalassinus. The ratio of the giant catfish and M. oleifera leaves were 100:0, 100:5, 100:10, and 100:15. The increase of $M$. oleifera leaves affected the characteristics of nugget products, viz., texture profile, protein, amino acids, cooking loss, and water holding capacity (WHC). Based on sensory tests, the four types of giant catfish nuggets with $M$. oleifera leaves did not differ significantly. Giant catfish nuggets and moringa leaves have the potential of being developed into products that can be consumed widely.
\end{abstract}

Keywords: Arius thalassinus; diversification; nugget; Moringa oleifera; physicochemical.

Practical Application: The addition of M. oleifera in giant catfish nuggets can be developed and consumed by the community to improve their nutritional status.

\section{Introduction}

Fried foods are very popular around the world with fried nuggets being one of the most acceptable fried foods (Ozen \& Singh, 2020). Nuggets are one of the processed animal food products that are consumed widely. Chicken meat is generally used as the main ingredient in the processing of nuggets. It can be replaced with other meats such as giant catfish meat and tuna fish meat which can be an alternative to chicken meat and a means of diversifying nugget products that have been developed (Özünlü et al., 2018; Pade, 2018). Fish nuggets have a fish-based formulation which is breaded, pre-fried and frozen, and it is usually prepared for consumption by deep frying (MittererDaltoé et al., 2014).

The development of fish nugget products is an innovation aimed at increasing fish consumption. Moreover, fish meat has advantages in the content of nutrients and functional compounds that are very beneficial to health (Mitterer-Daltoé et al., 2014). The giant catfish (Arius thalassinus) is a commercial fish whose production in 2011 was 90.980 tons. Generally, giant catfish are processed into dry fish or salted fish. The texture of giant catfish meat is thick, high in protein $18.56 \mathrm{~g} / 100 \mathrm{~g}$ (Abraham et al., 2017), rich in unsaturated fatty acids, namely $\mathrm{C}_{14}-\mathrm{C}_{22}$ and unsaturated fatty acids with several bonds 1-6 (Christie et al., 2016). Besides animal sources, vegetable commodities that have high protein content can be used as ingredients for making nuggets, namely Moringa oleifera. The protein content in M. oleifera leaves is about 25-30 g/100 g (Moyo et al., 2011; Iwansyah et al., 2016). Other valuable content of moringa leaves were macro and micronutrients, which are sources of natural antioxidants (Das et al., 2012; Moyo et al., 2011; Saini et al., 2016).

Giant catfish and $M$. oleifera leaves are Indonesia's local fish and plant that can be processed into nugget products with high nutritional value that are beneficial to health. Preliminary research showed that the addition of $50 \%$ fresh $M$. oleifera leaves produces nuggets with a dark green color and a bitter aftertaste, which is disliked by consumers. According to Zhang et al. (2019), the addition moringa in the product could increase the bitter taste and herbal flavor of moringa that is disliked by consumers. $M$. oleifera leaves have a flavor and characteristics that are less preferred. Hence, this study aimed to evaluate the physicochemical, nutritional, and organoleptic properties of fish nuggets with fresh $M$. oleifera leaves supplementation in order to create products that are nutritionally good and acceptable by the consumers.

\section{Materials and methods}

\subsection{Materials}

The giant catfish (Arius thalassinus) was bought from the traditional fish market in Subang City, West Java ProvienceIndonesia. Fresh Moringa oleifera leaves were collected from Pagaden District, Subang, West Java, Indonesia. Cornstarch, garlic, onion, shallot, salt, sugar, pepper powder, nutmeg powder, eggs, and bread flour were obtained from the Subang market. Hydrochloric acid, sulfuric acid, selenium mixed catalysts, 
n-hexane, boric acid, BCG (Bromchresol Green) indicators, and methyl red indicators obtained from Merck (Indonesia).

\subsection{Preparation of giant catfish nuggets with Moringa leaves supplementation}

Young, tender and fresh leaves of $M$. oleifera were weighed according to ratio with the giant catfish 0:100 (control), 5:100 (formula A), 10:100 (formula B), and 15:100 (formula C) and steamed for 15 minutes. Garlic (10 g), onion (30 g), shallot $(15 \mathrm{~g})$, ground pepper $(0.4 \mathrm{~g})$, nutmeg powder $(0.025 \mathrm{~g})$, and salt (4 g) were finely ground using a chopper, and then added with the leaves of M. oleifera, fillet of giant catfish, and ice. After that, cornstarch and sugar $(10 \mathrm{~g})$ were added to the chopper and mixed. The batter was placed on an aluminum pan and steamed for 30 minutes. The mixture was cooled at room temperature then cut to size $1 \times 5 \mathrm{~cm}$. The next process was coating using flour, egg whites, and bread flour. The nuggets were baked in the oven for 10 minutes, and then kept in the freezer.

\subsection{Total phenolics, total flavonoids, and antioxidant capacity of Moringa}

The fresh leaves of M. oleifera were washed and dried using a tray dryer at $45^{\circ} \mathrm{C}$ for 4 hours. The powder $(50 \mathrm{~g})$ was then soaked in distilled water $(500 \mathrm{~mL})$ at a ratio of 1:10 (w/v) for 24 hours by maceration methods ( 3 times). After that, the filtrate was concentrated, weighed, and dried at $50^{\circ} \mathrm{C}$ by a rotary evaporator (Rotavapor R-300 Buchi, Flawil, Switzerland). The total phenolic content, total flavonoidscontent, and antioxidant capacity by 1,1-diphenyl-2-picrylhydrazyl (DPPH) assay of moringa extract were determined according to the procedures described by Iwansyah et al. (2019). The content of phenolics was expressed as milligram of gallic acid equivalents (GAE) per $\mathrm{g}$ of extract. Flavonoid contents were expressed as $\mathrm{mg}$ of quercetin equivalents $(\mathrm{QE})$ per g of extract. Antioxidant capacity was expressed as inhibition \% of the absorbance at $515 \mathrm{~nm}$, using a UV-Vis spectrophotometer (Shimadzu UV-1900, Tokyo, Japan).

\subsection{Physics properties}

Physics properties $v i z$., texture profiles, water holding capacity, cooking loss of nugget samples were determined. Nugget texture profiles were tested using a texture analyzer model TA-XT2 (Stable Microsystems Ltd. Surrey, England, UK). The parameters obtained include hardness $(\mathrm{N})$; springiness $(\mathrm{mm})$; cohesiveness; adhesiveness (Ns); gumminess $\left(\mathrm{N} / \mathrm{mm}^{2}\right)$; and chewiness $(\mathrm{N} / \mathrm{mm})$ (Lukman et al., 2009). The water holding capacity (WHC) was measured based on the Excess-Water method with modification (Li et al., 1993). The cooking loss of the nuggets were measured by the weight difference before and after the cooking or frying process. Cooking loss was determined following the methods used by Lukman et al. (2009).

\subsection{Nutrition composition}

Nutritional composition viz., protein, moisture, fat, ash, carbohydrate of nugget samples was determined (Association of Official Analytical Chemists, 2004). Moisture and ash content was determined using the gravimetric method (Association of Official Analytical Chemists, 2004). The Buchi-Dumaster equipment was used to measure the protein content, fat was measured by the Weibull method, and carbohydrates were calculated (Association of Official Analytical Chemists, 2004).

\subsection{Amino acid profile}

The HPLC method was used to determine the amino acid profile. The cysteine, methionine, and tryptophan contents were determined after oxidation and alkaline hydrolysis, respectively (Bidlingmeyer et al., 1984; Gehrke et al., 1985; Landry \& Delhaye, 1992).

\subsection{Sensory characteristics}

The organoleptic test was carried out by hedonic testing using the scoring method. The test was seen through 5 levels, in which 1 is (extremely dislike) to 5 which is (extremely like). The organoleptic tests were conducted on 30 untrained panelists at the Research Center for Appropriate Technology.

\subsection{Statistical analysis}

The data were presented in means \pm standard deviations (Sd). The statistical analysis, using Microsoft Excel 2013 data processing software, was performed by one-way analysis of variance (ANOVA). The significant difference of data was determined by Duncan's test ( $\alpha=5 \%)$.

\section{Results and discussion}

\subsection{Total phenolics, total flavonoids and antioxidant capacity of Moringa}

The quantity of bioactive compounds, namely, phenols and flavonoids affected the quality of functional food or nutraceuticals. Table 1 shows the total phenolics, total flavonoid, and antioxidant capacity by the DPPH method of crude extract of M. oleifera. The amount of total phenolics, total flavonoids, and free radicals scavenging capacity were $9.19 \mathrm{mg}$ GAE$/ 100 \mathrm{~g}$ of extract, $2.53 \mathrm{mg}$ $\mathrm{QE} / 100 \mathrm{~g}$ of extract, and $41.26 \%$, respectively. The phenolics and flavonoids of $M$. oleifera can contribute to scavenge free radicals. The total flavonoids content correlated strongly with the antioxidant activity in galactopoietics plants (Iwansyah et al., 2016). This is also in agreement with Maisuthisakul et al. (2008) that reported the relationship between total phenolics, total flavonoids, and antioxidant capacity in 28 Thai plants. The high levels of phenolics compounds, especially flavonoids, make it a potential ingredient for meat products to improve

Table 1. Total phenolics, total flavonoids, and antioxidant capacity of moringa.

\begin{tabular}{cc}
\hline Properties & Moringa extract \\
\hline Total phenolics (mg GAE/100 g extract) & $9.19 \pm 0.42$ \\
Flavonoids (mg QE/100 g extract) & $2.53 \pm 0.22$ \\
Antioxidant capacity (\%) & $41.26 \pm 5.51$ \\
\hline
\end{tabular}

Data are expressed as mean \pm standard deviation $(n=3)$. GAE: gallic acid equivalent; $\mathrm{QE}$ : quercetin equivalent. 
their nutritional value and enhance the ability to scavenge free radicals (El-Anany et al., 2020).

\subsection{Texture profile}

The profile texture of nuggets including hardness, springiness, adhesiveness, cohesiveness, gumminess, and chewiness was shown in Table 2. The addition of M. oleifera leaves in fish nuggets increased the hardness, springiness, adhesiveness, cohesiveness, gumminess, and chewiness (Table 2). The hardness values can describe the required pressure needed to bite a nugget sample. M. oleifera dry leaves have a high fiber content of $12.5 \%$ (Gopalakrishnan et al., 2016). Dietary fibers that are generally present in vegetables are cellulose and noncellulose including hemicellulose, pectic substances, gums, mucilages and lignin (Dhingra et al., 2012). The fiber in the nugget matrix that uses starch and flour, causes inhibition of the gelatinization process (Kang \& Chen, 2015), thus increasing the hardness of giant catfish nuggets.

The springiness of elasticity can be interpreted as the recovery time between the ends of the first bite and the beginning of the second bite. Cohesiveness is the ratio of the area of pressure during the second compression to the first compression and it has no units. Meanwhile, gumminess is the product of the value of hardness with cohesiveness. The chewiness is the product of gumminess times springiness (Lukman et al., 2009). The addition of M. oleifera leaves increases the density of the dough, thereby reducing air in the nugget matrix. Hardness, springiness, gumminess, and chewiness are related to moisture content and air bound in the matrix (Swami et al., 2007).

\subsection{Nutritional composition}

Nutritional composition of the fish nugget based on $M$. oleifera, can be seen in Table 3. The addition of M. oleifera leaves to giant catfish nuggets significantly increased the ash and protein content, while the carbohydrates in nuggets decreased $(P<0.05)$, while the moisture and fat content were not significantly affected.
These results are in agreement with El-Anany et al. (2020) which reported that chicken nuggets formulated with various levels of cauliflower had higher ash. The addition of $M$. oleifera leaves increases the mineral content in the giant catfish nuggets. The macro mineral contents identified in M. oleifera included calcium, potassium, phosphorus, and sulphur (Moyo et al., 2011).

The increase in protein content is related to the high protein content of M. oleifera leaves ( $22.7 \mathrm{~g} / 100 \mathrm{~g}$ on dry matter basis). According to Wu et al. (2013), the crude protein content of moringa, on dry matter basis, ranges from 23.0 to $30.3 \%$. Moringa is reported to have high quality protein which is easily digested and is influenced by the quality of its amino acids. M. oleifera leaves contain the amino acids arginine, serine, aspartic acid, glutamic acid, glycine, threonine, alanine, tyrosine, proline, HO-Proline, methionine, valine, phenylalanine, isoleucine, leucine, histidine, lysine, cysteine, and tryptophan (Moyo et al., 2011). The addition of M. oleifera in the production of giant catfish nuggets can be developed and consumed by the community to improve their nutritional status.

\subsection{Cooking loss}

The cooking loss of catfish nuggets based on M. oleifera was shown in Figure 1. Figure 1 show that the addition of fresh $M$. oleifera into giant catfish nuggets did not significantly affect cooking loss compared to the control $(P>0.05)$. The cooking loss of giant catfish nuggets with $M$. oleifera addition ranges from $5.01-5.44 \%$. According to Lukman et al. (2009), cooking loss was related to the stability of the product emulsion or the stability of component interactions in the nugget matrix. The strength of the nuggets matrix was influenced by cornstarch and flour. Furthermore, the emulsion break or weak interaction of the ingredients will increase product cooking loss. The addition of flour can restrict starch granules, reduce the viscosity, and wrap the dough and finally affect the matrix (Dachana et al., 2010).

Table 2. The texture profile of giant catfish nuggets with $M$. oleifera leaves supplementation.

\begin{tabular}{|c|c|c|c|c|c|c|}
\hline Sample & Hardness $(\mathrm{N})$ & Adhesiveness (N.s) & Springiness $(\mathrm{mm})$ & Cohesiveness (N.s) & Gumminess $\left(\mathrm{N} / \mathrm{mm}^{2}\right)$ & Chewiness $(\mathrm{N} / \mathrm{mm})$ \\
\hline Control & 521.008 & -5.095 & 0.338 & 0.645 & 326.57 & 158.0679 \\
\hline A & 455.860 & -2.881 & 0.371 & 0.646 & 284.16 & 92.17607 \\
\hline B & 602.911 & -17.178 & 0.407 & 0.667 & 394.79 & 160.5828 \\
\hline C & 1537.434 & -22.092 & 0.465 & 0.680 & 1050.01 & 236.8051 \\
\hline
\end{tabular}

Data are presented as means $(\mathrm{n}=3)$. Values in the same column followed by different alphabets are significantly different by Duncan's test $(P<0.05)$. Note : N (Newton), N.s (Newton second).

Table 3. Nutrition composition of giant-catfish nugget with M. oleifera leaves supplementation.

\begin{tabular}{|c|c|c|c|c|}
\hline Parameter & Control & $\mathrm{A}$ & $\mathrm{B}$ & $\mathrm{C}$ \\
\hline Moisture (\%) & $49.57 \pm 0.16^{\mathrm{ab}}$ & $48.26 \pm 0.66^{c}$ & $49.66 \pm 0.60^{\mathrm{ac}}$ & $50.75 \pm 0.55^{\mathrm{b}}$ \\
\hline Ash (g/100 g) & $2.42 \pm 0.19^{\mathrm{a}}$ & $2.78 \pm 0.07^{\mathrm{b}}$ & $2.81 \pm 0.19^{b}$ & $2.73 \pm 0.10^{\mathrm{b}}$ \\
\hline Protein $(\mathrm{g} / 100 \mathrm{~g})$ & $12.20 \pm 0.09^{\mathrm{a}}$ & $12.42 \pm 0.29^{\mathrm{b}}$ & $12.68 \pm 0.07^{\mathrm{b}}$ & $13.11 \pm 0.02^{\mathrm{c}}$ \\
\hline Fat (g/100 g) & $0.88 \pm 0.01^{\mathrm{a}}$ & $0.89 \pm 0.71^{\mathrm{a}}$ & $0.89 \pm 0.04^{\mathrm{a}}$ & $0.94 \pm 0.64^{\mathrm{a}}$ \\
\hline Carbohydrates (g/100 g) & $35.23 \pm 0.08^{\mathrm{a}}$ & $35.95 \pm 0.41^{\mathrm{a}}$ & $34.27 \pm 0.68^{\mathrm{a}}$ & $32.78 \pm 1.27^{\mathrm{b}}$ \\
\hline
\end{tabular}

Data are presented as means \pm standard deviation $(n=3)$. Values in the same rows followed by different alphabets are significantly different by Duncan's test $(P<0.05)$. 


\subsection{Water Holding Capacity (WHC)}

Water holding capacity is used to determine the ability to hold water contained in tissues. The results of the water holding capacity of the fish nuggets with the addition of $M$. oleifera can be seen in Figure 2 .

Figure 2 shows that giant catfish nuggets without the addition of $M$. oleifera leaves had higher water holding capacity compared to giant catfish nuggets that were combined with $M$. oleifera leaves. The ability of water binding capacity affects the color, tenderness, suppleness, and texture of the product. Products that have a high water-holding capacity will have a chewy texture (Putri \& Yuwono, 2016). The addition of M. oleifera leaves will reduce the ability of the water holding capacity of the product,which in turn reduces the elasticity level of the result produced. Factors that influence WHC value are water, protein, and salt use. Based on the research by Kusnadi et al. (2012), the higher the percentage of meat in meatballs, the higher the holding capacity of the water produced. In chicken nuggets, the water holding capacity was influenced by the binding ability of proteins and fibers (Lukman et al., 2009).

\subsection{Sensory characteristics}

The organoleptic test was carried out to determine the characteristics of food ingredients with the help of the human senses, including the senses of sight, smell, taste, and hearing (Veggi et al., 2018). The organoleptic test results of fish nuggets combined with M. oleifera leaves can be seen in Figure 3.

Figure 3 shows that the addition of M. oleifera leaves had a significant difference in terms of color. Panelists increasingly disliked the darker color of the nuggets. The most preferred nugget color was control nugget that was not added with $M$. oleifera leaves because it has a bright color similar to nugget colorthat are widely available in the market. Taste and flavor parameters showed that there was no significant difference in the nuggets combined with $M$. oleifera leaves. The distinctive flavor on the nugget sample, which was given with the addition of $M$. oleifera leaves at various concentrations showed significant differences. The negligible difference in the flavor and taste of $M$. oleifera leaves detected in these nuggets might be due to the untrained panelists who were not conversant with the flavor and taste of $M$. oleifera leaves, so they lacked a good sensitivity to the appearance and sharpness of the flavor and taste of $M$. oleifera leaves.

The texture of the M. oleifera leaves combined with fish nuggets is slightly chewy and not significantly different across all the treatments. The addition of $M$. oleifera leaves reduced the level of elasticity in the nuggets but did not differ significantly. The nuggets that were combined with $M$. oleifera leaves have a texture that is less chewy than the control nuggets. This result was consistent with the results of the analysis of the water holding capacity, which showed that the treatment containing $M$. oleifera leaf has a lower water holding capacity than the control treatment. The low water holding capacity causes the product texture to decrease in its elasticity. On the other hand, this can also be caused by $M$. oleifera leaves which contain fiber, which is in the range of $7.92 \mathrm{~g} / 100 \mathrm{~g}$, so that the addition of $M$. oleifera leaves reduces the level of elasticity of the resulting

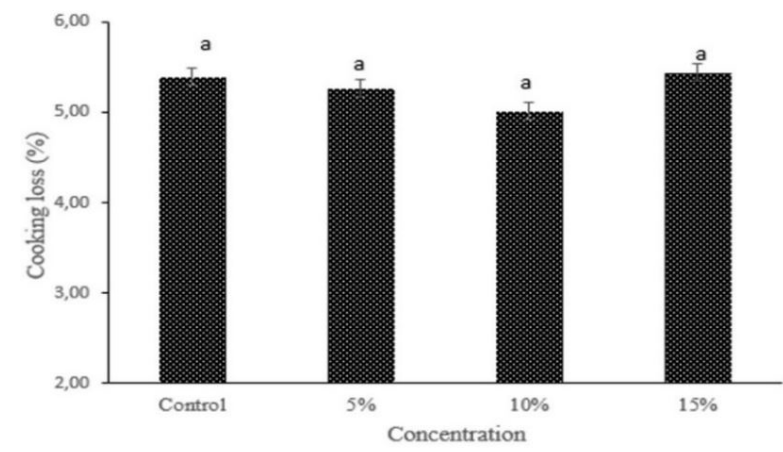

Figure 1.Cooking loss of giant catfish-moringa nuggets. Data are presented as means \pm error bars $(n=3)$. Values followed by different alphabets are significantly different by Duncan's test $(P<0.05)$.

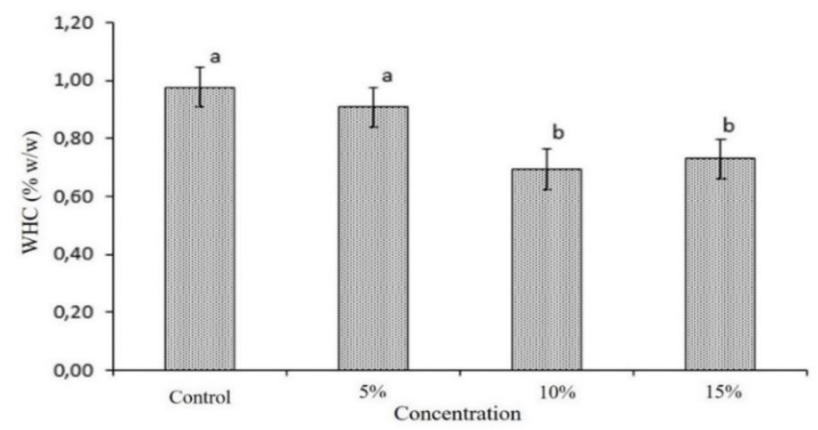

Figure 2. The binding capacity of giant fish-moringa nuggets. Data are presented as means \pm standard errors $(n=3)$. Values in the bar chart followed by different alphabets are significantly different by Duncan's test $(P<0.05)$.

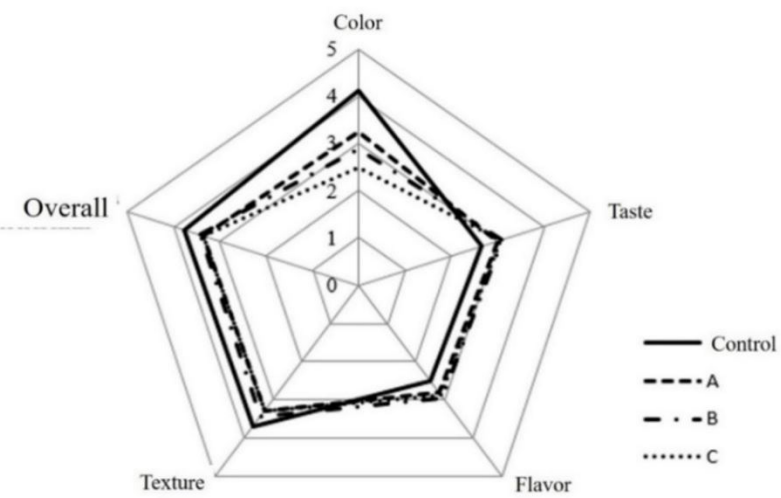

Figure 3.The organoleptic results of the giant fish-moringa nuggets. Data are presented as means $(n=3)$. Control: $0 \%$ of moringa; (A) $5 \%$ of moringa; (B) $10 \%$ of moringa; (C) $15 \%$ of moringa.

nugget texture. This result is in agreement with Nurlaila et al. (2018), which reported that increasing the moringa flour in the mackerel sausage, increases the hardness and reduces the springiness. Overall acceptance of panelists showed that the most preferred nuggets are the fish nuggets without the addition of $M$. oleifera leaves in terms of color, taste, flavor, and texture. The addition of $M$. oleifera leaves did not significantly affectacceptance of the taste, flavor, and texture. 
Table 4. Amino acids profile $(\mathrm{mg} / \mathrm{kg})$ of giant catfish nuggets with $M$. oleifera supplementation.

\begin{tabular}{lrc}
\hline \multicolumn{1}{c}{ Constituent } & Amount & Chicken nuggets \\
\hline Aspartic acid & 8971.86 & $11.33 \pm 1.27$ \\
Glutamic acid & 26033.44 & $13.23 \pm 1.70$ \\
Serine & 4119.67 & $5.85 \pm 0.67$ \\
Histidine & 2781.71 & $3.35 \pm 0.42$ \\
Glycine & 3983.84 & $4.73 \pm 0.60$ \\
Threonine & 4486.54 & $5.10 \pm 0.64$ \\
Arginine & 4496.74 & $8.70 \pm 0.96$ \\
Alanine & 4438.94 & $5.74 \pm 0.76$ \\
Tyrosine & 2488.84 & $4.04 \pm 0.38$ \\
Cysteine & 1337.82 & - \\
Valine & 2769.83 & $5.69 \pm 0.46$ \\
Methionine & 37.04 & $1.11 \pm 0.09$ \\
Phenylalanine & 3272.31 & $4.00 \pm 0.26$ \\
Isoleucine & 3741.06 & $4.63 \pm 0.15$ \\
Leucine & 7361.76 & $7.60 \pm 0.21$ \\
Lysine & 8076.40 & $5.69 \pm 0.70$ \\
Proline & 400.24 & $5.10 \pm 0.60$ \\
\hline
\end{tabular}

Data are presented as means of two replications.

*Source: Spiegelaar et al. (2019).

\subsection{Amino acids profile of giant catfish-Moringa nuggets}

Antioxidant properties of peptides are influenced by the amino acid composition of the peptide (Malomo et al., 2014). According to Wang \& De Mejia (2005), amino acids that cause antioxidant activity are tyrosin, trypthopan, methionine, lysine, cysteine and histidine. Donor protons can be made against radicals lacking electrons from aromatic residues of amino acids. This property improves the radical-scavenging properties of the amino acid residues (Rajapakse et al., 2005). Amino acid compositions of giant catfish nuggets combined with M. oleifera (Formula A) and compared with chicken nuggets (Spiegelaar et al., 2019) are shown in Table 4.

\section{Conclusion}

Based on the results, the addition of $M$. oleifera leaves affects the texture profile, nutritional value, water holding capacity (WHC), and cooking loss. The giant catfish-moringa nuggets meet the SNI requirements for fish nuggets SNI-7758: 2013 for protein and fat content. M. oleifera leaves significantly increases the protein and mineral content of giant catfish nuggets. The fish nuggets combined with $M$. oleifera is rich in amino acids. These nuggets have the potential of being developed into products that can be consumed by the community.

\section{References}

Abraham, B., Mahmud, A., Samuel, M., Yhdego, W., Kibrom, S., \& Habtom, W. (2017). Production of fish protein from Silver Catfish (Arius thalassinus). MOJ Food Processing \& Technology, 5, 4.

Association of Official Analytical Chemists - AOAC. (2004). Official methods of analysis (13th ed.). Washington: AOAC.

Bidlingmeyer, B. A., Cohen, S., \& Tarvin, T. (1984). Rapid analysis of amino acids using pre-column derivatization. Journal of Chromatography. B,
Biomedical Sciences and Applications, 336(1), 93-104. http://dx.doi. org/10.1016/S0378-4347(00)85133-6. PMid:6396315.

Christie, T. M., Ma'ruf, W. F., \& Susanto, E. (2016). Reducing the oxidation of manyung (Arius thalassinus) jambal roti with the implication of edible film during room temperature storage. Jurnal Peng dan Biotek, 5, 94.

Dachana, K. B., Rajiv, J., Indrani, D., \& Prakash, J. (2010). Effect of dried moringa (Moringa oleifera lam) leaves on rheological, microstructural, nutritional, textural and organoleptic characteristics of cookies. Journal of Food Quality, 33(5), 660-677. http://dx.doi. org/10.1111/j.1745-4557.2010.00346.x.

Das, A. K., Rajkumar, V., Verma, A. K., \& Swarup, D. (2012). Moringa oleiferia leaves extract: a natural antioxidant for retarding lipid peroxidation in cooked goat meat patties. International Journal of Food Science \& Technology, 47(3), 585-591. http://dx.doi. org/10.1111/j.1365-2621.2011.02881.x.

Dhingra, D., Michael, M., Rajput, H., \& Patil, R. T. (2012). Dietary fibre in foods: a review. Journal of Food Science and Technology, 49(3), 255266. http://dx.doi.org/10.1007/s13197-011-0365-5. PMid:23729846.

El-Anany, A. M., Ali, R. F. M., \& Elanany, A. M. M. (2020). Nutritional and quality characteristics of chicken nuggets incorporated with different levels of frozen white cauliflower. Italian Journal of Food Science, 32(1), 45.

Gehrke, C., Wall, L. Sr., Absheer, J., Kaiser, F., \& Zumwalt, R. (1985). Sample preparation for chromatography of amino acids: acid hydrolysis of proteins. Journal - Association of Official Analytical Chemists, 68(5), 811-821. http://dx.doi.org/10.1093/jaoac/68.5.811.

Gopalakrishnan, L., Doriya, K., \& Kumar, D. S. (2016). Moringa oleifera: a review on nutritive importance and its medicinal application. Food Science and Human Wellness, 5(2), 49-56. http://dx.doi.org/10.1016/j. fshw.2016.04.001.

Iwansyah, A. C., Damanik, R. M., Kustiyah, L., \& Hanafi, M. (2016). Relationship between antioxidant properties and nutritional composition of some galactopoietics herbs used in indonesia: a comparative study. International Journal of Pharmacy and Pharmaceutical Sciences, 8(12), 236. http://dx.doi.org/10.22159/ijpps.2016v8i12.14964.

Iwansyah, A., Julianti, W., \& Luthfiyanti, R. (2019). Characterization of nutrition, antioxidant properties, and toxicity of Physalis angulata $\mathrm{L}$. plant extract. Asian Journal of Pharmaceutical and Clinical Research, 12(11), 95-99. http://dx.doi.org/10.22159/ajpcr.2019.v12i11.35497.

Kang, H. Y., \& Chen, H. H. (2015). Improving the crispness of microwavereheated fish nuggets by adding chitosan-silica hybrid microcapsules to the batter. Lebensmittel-Wissenschaft + Technologie, 62(1), 740-745. http://dx.doi.org/10.1016/j.lwt.2014.04.029.

Kusnadi, D. C., Bintoro, V. P., \& Al-Baari, A. (2012). Water binding capacity, level of elasticity and protein content in meatballs combination of beef and rabbit meat. Jurnal Aplikasi Teknologi Pangan, 1, 2.

Landry, J., \& Delhaye, S. (1992). Simplified procedure for the determination of tryptophan of foods and feedstuffs from barytic hydrolysis. Journal of Agricultural and Food Chemistry, 40(5), 776-779. http://dx.doi. org/10.1021/jf00017a014.

Li, W. E. I., Bowers, J. A., Craig, J. A., \& Perng, S. (1993). Sodium tripolyphosphate stability and effect in ground turkey meat. Journal of Food Science, 58(3), 501-504. http://dx.doi.org/10.1111/j.1365-2621.1993. tb04310.x

Lukman, I., Huda, N., \& Ismail, N. (2009). Physicochemical and sensory properties of commercial chicken nuggets. Asian Journal of Food and Agro-Industry, 2, 171.

Maisuthisakul, P., Pasuk, S., \& Ritthiruangdej, P. (2008). Relationship between antioxidant properties and chemical composition of some 
Thai plants. Journal of Food Composition and Analysis, 21(3), 229240. http://dx.doi.org/10.1016/j.jfca.2007.11.005.

Malomo, S., He, R., \& Aluko, R. (2014). Structural and functional properties of hemp seed protein products. Journal of Food Science, 79(8), C1512. http://dx.doi.org/10.1111/1750-3841.12537. PMid:25048774.

Mitterer-Daltoé, M. L., Queiroz, M. I., Fiszman, S., \& Varela, P. (2014). Are fish products healthy? Eye tracking as a new food technology tool for a better understanding of consumer perception. LebensmittelWissenschaft + Technologie, 55(2), 459-465. http://dx.doi.org/10.1016/j. lwt.2013.10.013.

Moyo, B., Masika, P. J., Hugo, A., \& Muchenje, V. (2011). Nutritional characterization of Moringa (Moringa oleifera Lam.) leaves. African Journal of Biotechnology, 10(60), 12925-12933. http://dx.doi. org/10.5897/AJB10.1599.

Nurlaila, N., Sukainah, A., \& Amiruddin, A. (2018). Pengembangan produk sosis fungsional berbahan dasar ikan tengiri (Scomberomorus sp.) dan tepung daun kelor (Moringa oleifera L). Jurnal Kajian dan Penelitian Biologi, 2(2), 105. http://dx.doi.org/10.26858/jptp.v2i2.5165.

Ozen, E., \& Singh, R. K. (2020). Heat transfer in breaded and nonbreaded chicken nuggets baked in a pilot-scale radiant wall oven. Lebensmittel-Wissenschaft + Technologie, 124, 109107. http://dx.doi. org/10.1016/j.lwt.2020.109107.

Özünlü, O., Ergezer, H., \& Gökçe, R. (2018). Improving physicochemical, antioxidative and sensory quality of raw chicken meat by using acorn extracts. Lebensmittel-Wissenschaft + Technologie, 98, 477484. http://dx.doi.org/10.1016/j.lwt.2018.09.007.

Pade, S. (2018). Analisis tingkat penerimaan nugget ikan cakalang (Katsuwonus pelamis L.) dengan penambahan bonggol pisang. Journal of Agritech Science, 2(2), 90-95.

Putri, A. D., \& Yuwono, S. (2016). Effects of addition of tofu pulp and type of coagulant on making fibrous tofu. Journal of Food AgroIndustry, 4(1), 321.

Rajapakse, N., Mendis, E., Jung, W. K., Je, J. Y., \& Kim, S. K. (2005). Purification of a radical scavenging peptide from fermented mussel sauce and its antioxidant properties. Food Research International, 38(2), 175-182. http://dx.doi.org/10.1016/j.foodres.2004.10.002.

Saini, R. K., Sivanesan, I., \& Keum, Y. S. (2016). Phytochemicals of Moringa oleifera : a review of their nutritional, therapeutic and industrial significance. Journal of Biotechnology, 6(2), 203. PMid:28330275.

Spiegelaar, N., Martin, I. D., \& Tsuji, L. J. S. (2019). Indigenous subarctic food systems in transition: amino acid composition (including Tryptophan) in wild-harvested and processed meats. International Journal of Food Sciences, 2019, 1-14. http://dx.doi. org/10.1155/2019/7096416. PMid:31346512.

Swami, S. B., Das, S. K., \& Maiti, B. (2007). Texture profile analysis of cooked sun dried nuggets (bori) prepared with different levels of moisture content and percent air incorporation in its batter. International Journal of Food Engineering, 3(5), 1. http://dx.doi. org/10.2202/1556-3758.1155.

Veggi, N., Voltarelli, F. A., Pereira, J. M. N., Silva, W. C., Navalta, J. W. Cavenaghi, D. F. L. C., \& Barros, W. M. (2018). Quality of high-protein diet bar plus chia (Salvia hispanica L. ) grain evaluated sensorially by untrained tasters. Food Science and Technology, 38(Suppl. 1), 306-312. http://dx.doi.org/10.1590/fst.22317.

Wang, W., \& De Mejia, E. G. (2005). A new frontier in soy bioactive peptides that may prevent age-related chronic diseases. Comprehensive Reviews in Food Science and Food Safety, 4(4), 63-78. http://dx.doi. org/10.1111/j.1541-4337.2005.tb00075.x. PMid:33430553.

Wu, D., Cai, Z., Wei, Y., Zhang, C., Liang, G., \& Guo, Q. (2013). Research advances in moringa as a new plant protein feed. Chinese Journal of Animal Nutrition, 25(3), 503.

Zhang, T., Jeong, C. H., Cheng, W. N., Bae, H., Seo, H. G., Petriello, M. C., \& Han, S. G. (2019). Moringa extract enhances the fermentative, textural, and bioactive properties of yogurt. Lebensmittel-Wissenschaft + Technologie, 101, 276-284. http://dx.doi.org/10.1016/j.lwt.2018.11.010. 